\title{
Anthropogenic Transformation Disconnects a Lowland River From Contemporary Carbon Stores in Its Catchment
}

\author{
Jörg Tittel, ${ }^{1 *}$ Andreas Musolff, ${ }^{2}$ Karsten Rinke, ${ }^{1}$ and Olaf Büttner ${ }^{1}$ \\ ${ }^{1}$ UFZ-Helmholtz-Centre for Environmental Research, Brückstraße 3a, 39114 Magdeburg, Germany; ${ }^{2}$ UFZ-Helmholtz-Centre for \\ Environmental Research, Permoserstr. 15, 04318 Leipzig, Germany
}

\begin{abstract}
Rivers transport carbon from continents to oceans. Surprisingly, this carbon has often been found to be centuries old, not originating from contemporary plant biomass. This can be explained by anthropogenic disturbance of soils or discharge of radiocarbon-depleted wastewater. However, land enclosure and channel bypassing transformed many rivers from anabranching networks to single-channel systems with overbank sediment accumulation and lowered floodplain groundwater tables. We hypothesized that human development changed the fluvial carbon towards older sources by changing the morphology of watercourses. We studied radiocarbon in the Elbe, a European, anthropogenically-transformed lowland river at discharges between low flow and record peak flow. We found that the inorganic carbon, dissolved organic carbon (DOC) and particulate organic carbon was aged and up to 1850 years old. The $\Delta^{14} \mathrm{C}$ values remained low and invariant up to median discharges,
\end{abstract}

Received 14 January 2021; accepted 18 June 2021;

published online 2 August 2021

Supplementary Information: The online version contains supplementary material available at https://doi.org/10.1007/s10021-021-0067 5-z.

Author's Contribution JT conceived the study, analyzed data and led the writing of the paper. OB analyzed data and estimated the discharge of wastewater. AM, KR and $\mathrm{OB}$ substantially contributed in the writing process and to revisions.

*Corresponding author; e-mail: joerg.tittel@ufz.de indicating that the sources of modern carbon (fixed after 1950) were disconnected from the river during half of the time. The total share of modern carbon in DOC export was marginal $(0.04 \%), 72 \%$ of exported DOC was older than 400 years. This was in contrast to undisturbed forested subcatchments, $72 \%$ of whose exported DOC was modern. Although population density is high, mass balances showed that wastewater did not significantly affect the $\Delta^{14} \mathrm{C}$-DOC in the Elbe river. We conclude that wetlands and other sources of contemporary carbon were decoupled from the anthropogenically transformed Elbe stream network with incised stream bed relative to overbank sediments, shifting the sources of fluvial carbon in favor of aged stores.

Key words: radiocarbon; DOC; POC; TIC; wetland; geomorphology; floodplain; soil; isotope; Elbe.

\section{HighLIGHTS}

- Inorganic and organic carbon exported by a lowland river was up to 1850 years old

- Recently fixed organic carbon was found only in the largest flood event since 1727

- Young floodplain carbon was decoupled by human changes of the stream geomorphology 


\section{INTRODUCTION}

Rivers link the carbon cycles of continents and oceans. They transport about 0.9 Pg carbon per year from land ecosystems to coastal oceans, an amount equivalent to one fourth of the annual terrestrial net carbon fixation (Drake and others 2018). Over geological timescales, the riverine transport of organic carbon and its subsequent burial in oceanic sediments represents the second largest atmospheric $\mathrm{CO}_{2}$ sink (Berner 2003; Galy and others 2007). However, only the burial of contemporary photosynthetic matter removes carbon from the rapidly cycling pools of the biosphere. The burial of carbon from old stocks does not lower atmospheric $\mathrm{CO}_{2}$ levels. For this reason, measuring the age of river carbon became of particular interest. The early observation that organic carbon in rivers can be hundreds of years old and depleted in radiocarbon $\left(\Delta^{14} \mathrm{C}<0 \%\right.$, Raymond and Bauer 2001) was surprising und related later to anthropogenic disturbance (Sickman and others 2007; Griffith and others 2009). The presumably young carbon age of river carbon may be hidden by carbon from old sources mobilized by soil perturbation (Sickman and others 2007) such as construction and tilling as well as by discharges from urban and industrial sources (Hossler and Bauer 2013). In particular, the effluent of wastewater treatment plants (WWTPs) was found to contain a radiocarbon-devoid fraction of petrochemical surfactants (Griffith and others 2009). A comprehensive data analysis revealed that the age of stream dissolved organic carbon (DOC) increased with increasing population density and increasing proportion of cultivated and urban area of the catchment (Butman and others 2014).

A causality between population density, wastewater discharge, catchment soil perturbation and DOC age is plausible, however, an alternative hypothesis can also be conceived: The anthropogenic transformation of the original river networks changes the hydrological connection of the carbon sources in their catchments. Many of today's densely populated areas were settled along the rivers and historically altered by agriculture. Early pre-deforestation rivers were either braided or anabranching wetland or woodland systems with very limited overbank alluviation (Brown and others 2018). In Europe and later in North America and Australia, arable cultivation, land enclosure and channel bypassing has led to flow confinement and floodplain terrestrialisation. In upriver regions, watermills and channel obstructions became a ubiquitous feature of small rivers. As a conse- quence, channel networks have been buried under thick sediments and abandoned, with a reduction of storage of sediment in the remaining channel and a lowering of the floodplain groundwater table (Brown and others 2018; Tena and others 2020; Shen and others 2021).

An incision of the stream bed relative to the floodplain surface soil ultimately leads to a vertical separation of recently fixed surface soil carbon from the floodplain groundwater table and thus from the layer where stream discharge is mainly generated. Consequently, deeper soil layers with aged stocks may become the dominating source of river carbon. Here, we hypothesize that human settlement changed the carbon in lowland rivers indirectly via transformation of the geomorphology of watercourses rather than by direct disturbance of soils. We studied stable carbon $\left({ }^{13} \mathrm{C}\right)$ and radiocarbon $\left({ }^{14} \mathrm{C}\right)$ isotopes during extreme low flow, median flow and extreme high flow in the Elbe river, draining the fourth largest catchment in Central and Western Europe. We analyzed the shifts in isotope composition along the discharge gradient to disentangle the sources of the fluvial carbon. To assess if discharge of WWTP effluent was a significant source of old DOC found in Elbe river we utilized mass balance calculations. To evaluate the potential impact of soil perturbation on stream carbon age, we compared the response of ${ }^{14} \mathrm{C}$-DOC to increasing discharges in the main Elbe river and in entirely forested and morphologically rather unchanged subcatchments. Finally, we estimated the share of modern and aged carbon in total DOC export of the Elbe river and of undisturbed subcatchments to conclude on the role of human transformation of the main river network and the connection of recently produced carbon stores in floodplains to the stream.

\section{Site Description and Methods}

\section{Study Site}

The Elbe river, called Labe in Czech, is a glacial lowland stream, the upper reaches are located in mountainous areas (Figure 1). Its catchment has a size of $148268 \mathrm{~km}^{2}$. The mean annual precipitation amounts to $628 \mathrm{~mm}$, the mean annual air temperature is $8-9{ }^{\circ} \mathrm{C}$ in the lowlands and $1-3^{\circ} \mathrm{C}$ in the higher regions of the mountain ranges. The German part of the Elbe is free flowing until the tidal section whereas the upper Czech part as well as the tributaries Vltava, Mulde and Saale are regulated by dams. The glaciofluvial valley was formed in the Weichselian glaciation, which ended 10-12 


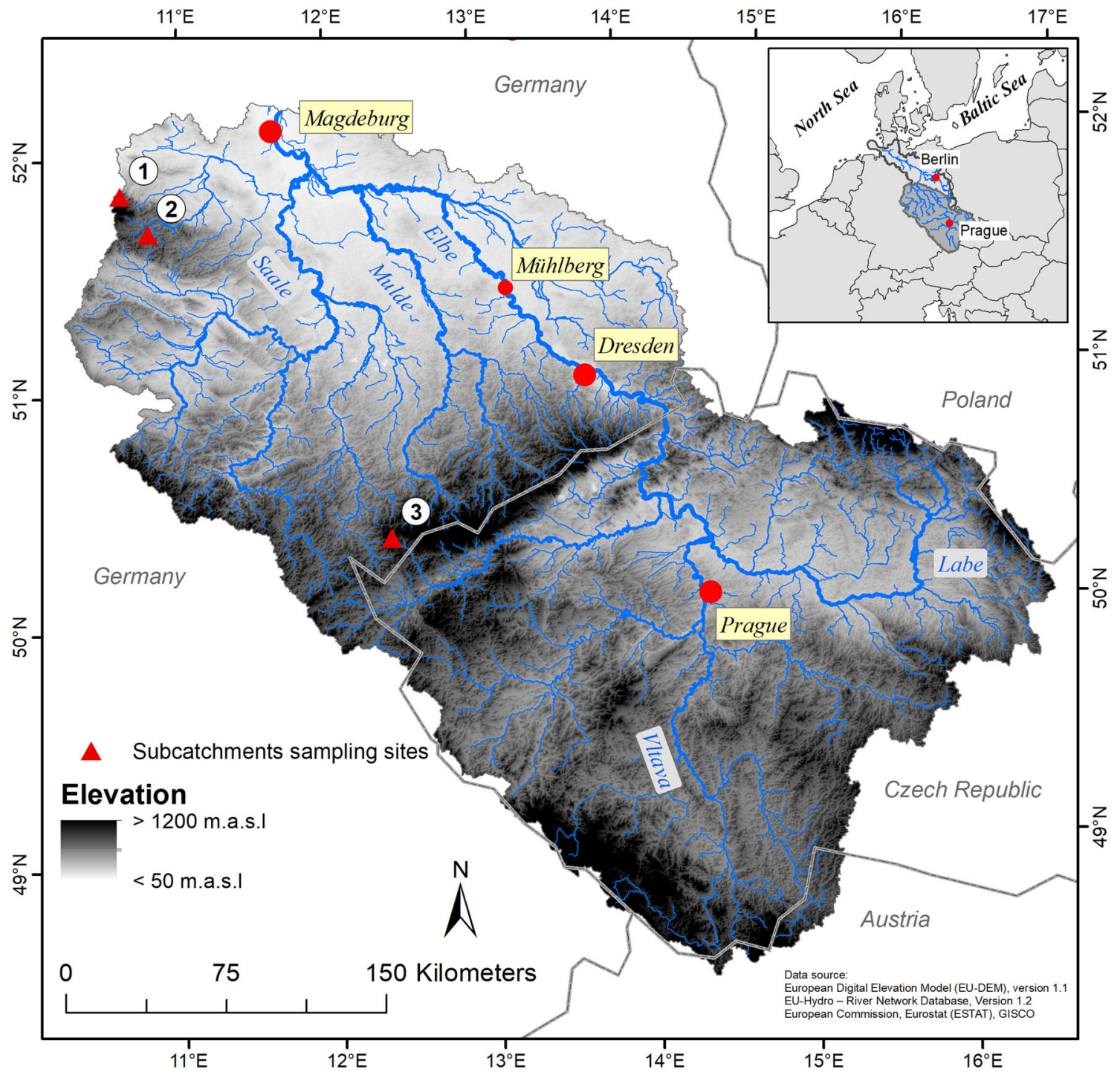

Figure 1. Catchment map with the main sampling station at Magdeburg and the areas (1-3) were the sampled subcatchments are located.

kyrs ago. Melting waters eroded a vast channel that became the large bed of the Elbe river moving gravel and sand downstream. (Schneeweiss and Schatz 2014). These sediments still form the subsurface of the river banks. With beginning of the Middle Ages large forests were cleared. Dykes were built from the twelfth century, which caused a confinement of the runoff cross-section. This led to higher flow velocities in the channel, dramatic erosion and to deposition of thick sediments in the floodplains (Friese and others 2000; Krüger and others 2006). In Northern Czechia, downstream the mouth of the Vltava river (Figure 1), projects for channelization and damming date back to the eighteenth century. Levees were established along the riverbank. Most fluvial islands disappeared after the construction of modern dams combined with lock chambers in the twentieth century (Raška and others 2017). Anabranching patterns were modified by channel straightening and abandonment of courses (Brázdil and others 2011). In the middle part of the river, a program to improve navigation began in the second half of the nineteenth century. On a large scale, dykes and groynes were constructed (Figure 2C), which substantially narrowed the floodplains (Koenig and others 2012). As a result, the stretch between Mühlberg and the mouth of the Saale river (Figure 1) experienced strong erosion of the river bed of up to $2 \mathrm{~cm}$ per year during the last century. Crossings and breakthroughs had shortened the course of the river by $5.6 \mathrm{~km}$ per $100 \mathrm{~km}$ (Rommel 

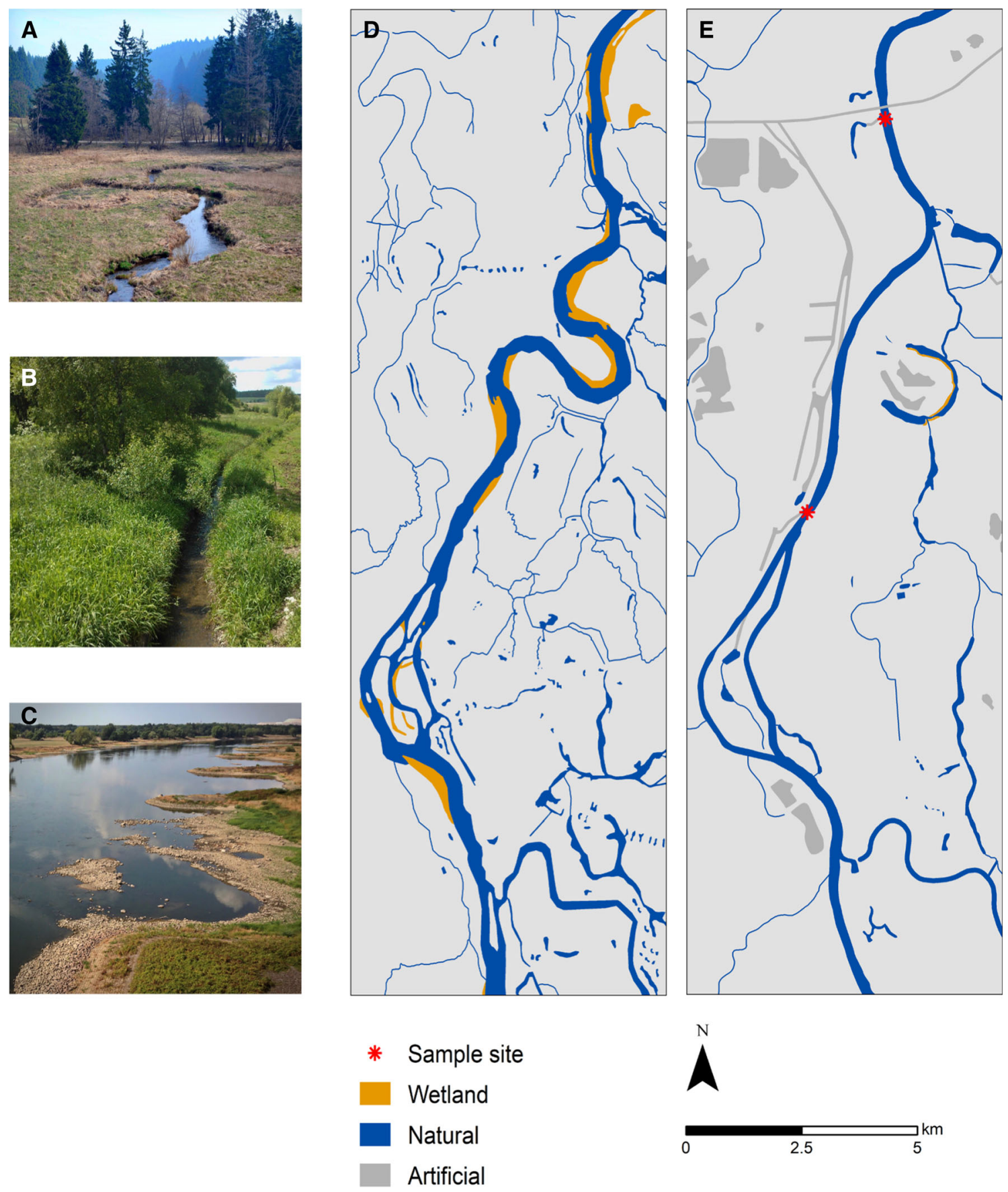

Figure 2. The Elbe river at the sampling site Magdeburg and upstream located subcatchments. A undisturbed headwater subcatchment, B anthropogenically modified subcatchment, C main channel at the northern sampling site during low flow, bank revetment by armour stones prevented lateral migration, groins narrowed the channel and increased its water depth for navigation, D Elbe river and floodplain waters between 1739 and 1787 at Magdeburg, E same river stretch as left but in its present state with sampling points. The direction of flow is from south to north.

2001). At the sampling station (Figure 1) the low water levels decreased by $1.6 \mathrm{~m}$ between 1893 and 1990 after narrowing and straightening of the river to improve navigation (Koenig and others 2012). Almost all wetlands were lost compared to the mid- eighteenth century (Figure 2D, E). Floodplain water courses lost their connection to the river or dried up completely.

Water samples were taken at the city of Magdeburg. We used a bridge at the northern edge of the 
city $\left(52.15439^{\circ} \mathrm{N}, 11.67358^{\circ} \mathrm{E}\right.$, Herrenkrug, Figure 1, Figure 2E) for the first two samplings at the beginning of the major flood (see below). As the water level continued to rise, this station was no longer accessible, so all subsequent samples, including those of median and low flow situations, were taken from a bridge $9 \mathrm{~km}$ downstream $\left(52.23105^{\circ} \mathrm{N}, \quad 11.70124^{\circ} \mathrm{E}\right.$, Kanalbrücke). Discharges and stage heights were monitored at the gauge station Strombrücke (German Federal Institute of Hydrology, BfG), located $12 \mathrm{~km}$ upstream the main sampling station in the city of Magdeburg $\left(52.12951^{\circ} \mathrm{N}, 11.64411^{\circ} \mathrm{E}\right.$; elevation $\left.40 \mathrm{~m}\right)$. The size of the associated catchment area is $94942 \mathrm{~km}^{2}$, $42 \%$ of which is used as arable land, $11 \%$ as pasture, $32 \%$ as forest and $8 \%$ as urban areas (EEA 2018). The population density equals to 145 individuals $\mathrm{km}^{-2}$ (eurostat 2015).

In addition to the large Elbe river catchment, we also analyzed data from subcatchments (Figure 1) from which DOC radiocarbon measurements were available in earlier studies. The dataset comprises 23 subcatchments with a total of 74 samples (Table S1). Arable land constituted 0-25\%, pasture $0-59 \%$, urban area $0-4 \%$ and the sum of arable land, pasture plus urban area $0-81 \%$ in the subcatchments. Almost all streams were inflows to drinking water reservoirs; wastewater and rainwater from villages was diverted out of the catchment. Therefore, significant impacts of wastewater on stream $\Delta^{14} \mathrm{C}$-DOC values can be excluded. A subset of 30 samples from 10 streams located in entirely forested catchment areas (without settlements) was used as a reference for stream DOC not affected by soil disturbance (Figure 2A, B).

\section{Sampling}

Samples for carbon concentration and isotopic composition as well as for major ions were taken at nine occasions between June 2013 and August 2018. They include two extreme low flow periods (154 and $136 \mathrm{~m}^{3} \mathrm{~s}^{-1}$ ), two median flow situations (443 and $442 \mathrm{~m}^{3} \mathrm{~s}^{-1}$ ), four high flows during the rising and falling limb of a major flood event $\left(1380-4470 \mathrm{~m}^{3} \mathrm{~s}^{-1}\right)$ and the peak flow $\left(5010 \mathrm{~m}^{3} \mathrm{~s}^{-1}\right)$. For a statistical classification of these discharges see Results and Discussion. The flood was caused by extremely high rainfalls up to $200 \mathrm{~mm}$ between 30 May and 02 June 2013 in combination with an exceptionally high antecedent soil wetness, which exceeded the previous maximum wetness in $40 \%$ of the areas (Belz and others 2014). In addition, we took samples at 34 occasions for carbon concentra- tion and ions $\left(\mathrm{K}^{+}, \mathrm{Ca}^{2+}\right)$ between June 2013 and August 2015 (Table S2).

We sampled the river on the left and right side, halfway between the middle of the river and the banks. We collected water from 0.5 to $1 \mathrm{~m}$ depth using a Limnos sampler (Turku, Finland). The depth of the river was $0.8-2.8 \mathrm{~m}$ at low flow and median flow and 4-7 $\mathrm{m}$ at high flow and peak flow. During the event we took grab samples from the surface because the high flow velocity $\left(1.7 \mathrm{~m} \mathrm{~s}^{-1}\right.$, estimated by progression of the flood crest) and the distance between bridge and water surface $(>20 \mathrm{~m})$ did not allow to use the sampler. We cannot exclude that by taking samples only on the river surface we have not representatively captured the coarse fraction of particulate organic carbon (POC) from deeper layers. Because of the high flow velocity and turbulence, however, we assume that the error was rather small. For DOC and POC concentration and isotope analyses, we collected water samples of $2 \mathrm{~L}$ volume in glass stoppered brown glass flasks. The glassware was acid-rinsed twice $(0.1 \mathrm{~N} \mathrm{HCl})$ and baked $\left(500{ }^{\circ} \mathrm{C}, 4 \mathrm{~h}\right)$. For total inorganic carbon (TIC) concentration, ${ }^{13} \mathrm{C}$-TIC and ${ }^{14} \mathrm{C}$-TIC isotope samples we used $100 \mathrm{~mL}$ crimp-capped (aluminum, butyl/PTFE) flasks, $50 \mathrm{~mL}$ crimp-capped brown glass vials and $1 \mathrm{~L}$ brown glass bottles with solid ground glass joints, respectively. The ${ }^{13} \mathrm{C}$-TIC samples were stabilized by $0.2 \mathrm{~mL}$ of a $\mathrm{HgCl}_{2}$ solution $(1 \%)$. For potassium, calcium and inorganic suspended solid (ISS) analyses, samples of $500 \mathrm{~mL}$ volume were also derived.

\section{Analyses}

In the laboratory, the samples were processed as described earlier (Tittel and others 2013). At the sampling day, the DOC samples were filtered (GF/F, pre-combusted $500{ }^{\circ} \mathrm{C}, 4 \mathrm{~h}$ ). Two subsamples of $100 \mathrm{~mL}$ were derived and used for DOC concentration measurement or treated by $\mathrm{H}_{3} \mathrm{PO}_{4}$ (final $\mathrm{pH}<1$ ) and $\mathrm{HgCl}_{2}$ to be stored for ${ }^{13} \mathrm{C}$-DOC analysis. The remaining $1.8 \mathrm{~L}$ were enriched by evaporation at $60{ }^{\circ} \mathrm{C}$, acidified and freeze dried for DOC radiocarbon measurement. For POC concentration and isotope analysis, the GF/F filters used before for DOC filtration were dried $\left(60{ }^{\circ} \mathrm{C}\right)$ and stored after exposure to concentrated $\mathrm{HCl}$ vapor (Lorrain and others 2003). To collect inorganic carbon for ${ }^{14} \mathrm{C}$ analysis, the samples were acidified and outstripped. The $\mathrm{CO}_{2}$ was precipitated in a prefiltered barium hydroxide solution. ISS samples were filtered (pre-combusted and weighted GF/F), combusted $\left(500{ }^{\circ} \mathrm{C}, 4 \mathrm{~h}\right)$ and stored in a desiccator. 
The concentration of TIC and DOC was quantified using a Dimatoc 2000 analyzer (Analysentechnik, Essen, Germany). For POC a Vario EL analyzer (Elementar, Hanau. Germany) was used. The concentration of potassium and of calcium was measured by ion chromatography (ICS-3000, Dionex, Sunnivale, USA). Stable carbon isotope TIC and DOC samples of the year 2013 were sent in duplicates to the Colorado Plateau Stable Isotope Laboratory, Flagstaff, USA. The samples of the following years as well as all ${ }^{13} \mathrm{C}$-POC samples were analyzed at the Stable Isotope Facility at the University of California, Davis, USA using isotoperatio mass spectrometry (IRMS). The $\delta^{13} \mathrm{C}$ values produced in both laboratories were expressed relative to standard Vienna PeeDee Belemnite. Radiocarbon abundances were measured by accelerator mass spectrometry (AMS) at the Leibniz Laboratory for Radiometric Dating and Stable Isotope Research, Kiel, Germany. The results $\left(\Delta^{14} \mathrm{C}\right)$ refer to the oxalic acid II standard and were corrected for process and instrument blanks and for fractionation (Stuiver and Polach 1977).

\section{Calculations}

We analyzed the TIC and DOC isotope dynamics using Keeling plots (Pataki and others 2003). They show the isotope composition as a function of the inverse of the carbon concentration. A perfect linear relationship would mean that the isotopic composition can solely be described by the mixing of two endmembers. The intersection of the regression line with the $\mathrm{y}$-axis depicts the isotopic value at infinite concentration, i.e. the signature of one endmember. To estimate if wastewater inputs were significant for the age of the stream DOC, we calculated the $\Delta^{14} \mathrm{C}$ of the DOC fraction that was not derived from wastewater effluent $\left({ }^{14} \mathrm{C}_{\mathrm{nw}}\right)$ on the basis of a mass balance:

$$
\begin{gathered}
{ }^{14} \mathrm{C}_{\text {stream }}={ }^{14} \mathrm{C}_{\mathrm{ww}} \cdot F_{\mathrm{ww}}+{ }^{14} \mathrm{C}_{\mathrm{nw}} \cdot F_{\mathrm{nw}} \\
F_{\mathrm{ww}}+F_{\mathrm{nw}}=1
\end{gathered}
$$

${ }^{14} \mathrm{C}_{\text {stream }}$ equals $\Delta^{14} \mathrm{C}$ measured. ${ }^{14} \mathrm{C}_{\mathrm{ww}}$ equals $\Delta^{14} \mathrm{C}$ of wastewater. In two scenarios, we used either the 0.25 or the 0.75 quantil of published $\Delta{ }^{14} \mathrm{C}$ DOC values of WWTP effluent as an endmember $\left(-202 \%,-114 \%\right.$, Table S3). $F_{\mathrm{ww}}$ equals fraction of wastewater calculated as the quotient of a constant amount of wastewater and a total discharge that varied between hydrological situations. $F_{n w}$ equals fraction of non-wastewater. The amount of wastewater was estimated for WWTP's with more than 2000 population equivalents as the sum of wastewater from households assuming an average per capita water consumption of $123 \mathrm{~L} \mathrm{day}^{-1}$ and the WWTP storm water effluent plus WWTP infiltration water, each of which estimated as half of the amount of wastewater from households (Table S4). DOC concentration was not considered in our calculation as it was not different in the Elbe river $\left(6.9 \pm 2.0 \mathrm{mg} \mathrm{L}^{-1}\right)$ from concentrations typically analyzed in WWTP effluent (for example, $8.7 \pm 4 \mathrm{mg} \mathrm{L}^{-1}$ in WWTPs of the United States, Griffith and others 2009). Assuming similar DOC concentrations in the river and in WWTP effluent, we also calculated the share of wastewater DOC in total DOC exports as the quotient of wastewater discharge $\left(44 \mathrm{~m}^{3} \mathrm{~s}^{-1}\right.$ at the sampling station, Table S4) to mean discharge $\left(549 \mathrm{~m}^{3} \mathrm{~s}^{-1}\right)$.

To estimate the share of modern carbon $\left(\Delta{ }^{14} \mathrm{C}>0\right.$, fixed after 1950$)$ in DOC exports of the Elbe river, we defined 51 classes of stream discharge $\left(k=100,200,300 \ldots 5100 \mathrm{~m}^{3} \mathrm{~s}^{-1}\right)$. Along the range of discharges, we calculated corresponding ${ }^{14} \mathrm{C}$ ages of DOC using the relationship between measured discharge and measured DOC radiocarbon values (Figure $3 \mathrm{~B}$ ). The age of the DOC was not corrected for WWTP effluent as it turned out that the wastewater supply did not significantly change the stream $\Delta^{14} \mathrm{C}$-DOC (see Results and Discussion). To calculate the exports of DOC within the discharge classes we derived the following equation based on the approach of Jawitz and Mitchell (2011):

$$
E_{k}(\%)=100 \frac{Q_{k}^{*} F_{k} D O C_{k}}{\sum_{k=100}^{5100}\left(Q_{k}^{*} F_{k} D O C_{k}\right)}
$$

$E_{k}$ equals export of DOC in discharge class $k$ relative to the overall export; $Q_{k}^{*}$ equals discharge class $k$ minus the amount of supplied wastewater $\left(44 \mathrm{~m}^{3} \mathrm{~s}^{-1}\right.$, Table S4); $F_{k}$ equals the fraction of time the discharge of class $k$ was observed; $D O C_{k}$ equals concentration of DOC in class $k$, estimated as function of discharge (Figure 3A). The DOC concentration was assumed to be not different between the river and wastewater (see above) and therefore not corrected. Thus, a DOC age and an export could be assigned to each discharge class $k$ (Table S5). We finally defined DOC age classes (modern, $<400,<800$ $\ldots<2000$ years B.P.) and cumulated the associated exports to obtain a time-integrated age distribution of Elbe river DOC export. It was compared with the age distribution of DOC exported from 10 forested subcatchments of the Elbe river that have been studied previously (Table S1). Here, relationships between discharge and DOC concentration or DOC age were not available. We assigned the DOC export on each 

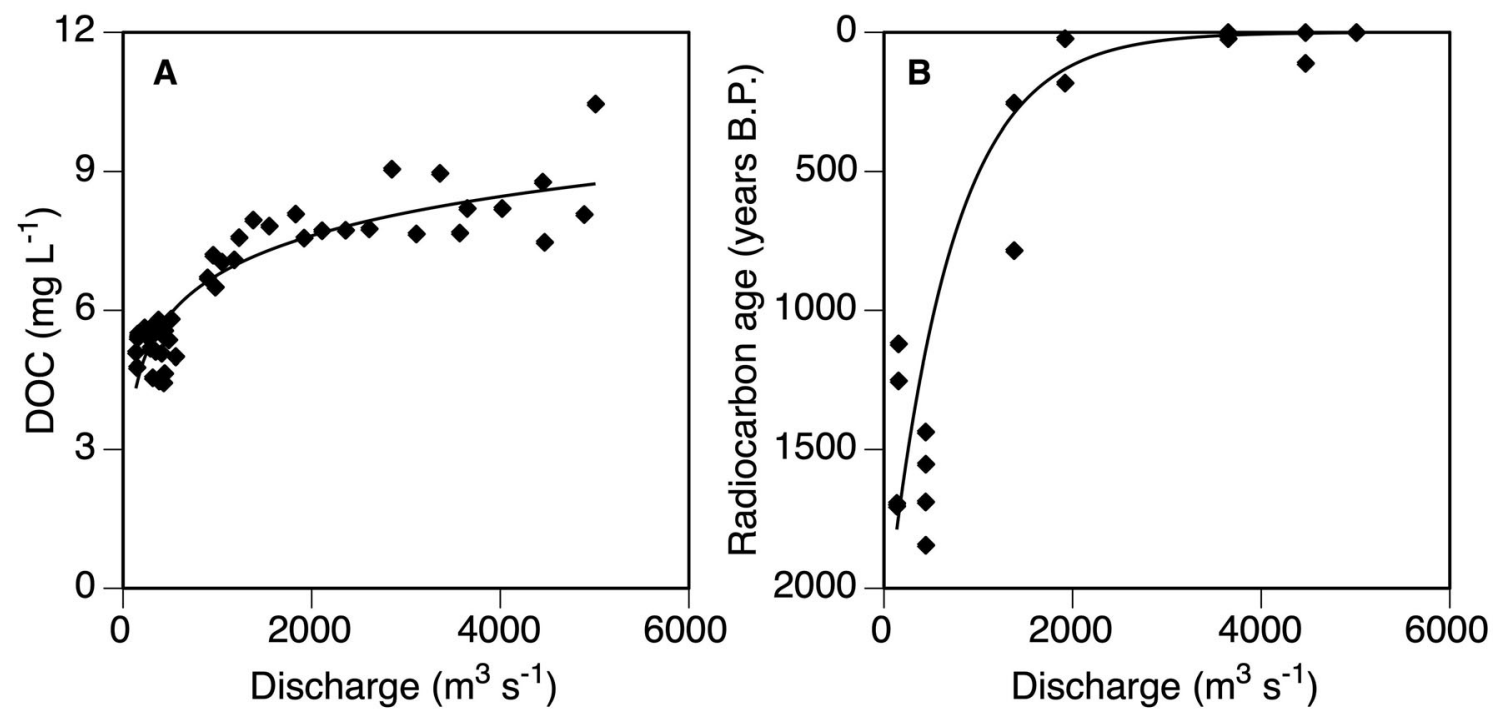

Figure 3. Relationships between discharge and measured DOC concentration and DOC age. For three samples containing modern carbon $\left(\Delta^{14} \mathrm{C}>0\right)$ an age of 1 year B.P. (that is, before 1950) was assumed. Modern means that a sample contained carbon fixed after 1950. Regressions: A DOC $=1.223 \cdot \ln (\mathrm{Q})-1.688, R^{2}=0.80, P<0.00001, N=43(\mathrm{mean}$ values of samples from left and right side of the stream used); $\mathbf{B}$ DOC ${ }^{14} \mathrm{C}$ age $=2181 \cdot \mathrm{e}^{(-0.001459 \cdot \mathrm{Q})}, R^{2}=0.83$, $P<0.00001, N=18$. Data are available in Table S2.

sample day to one of the DOC age classes defined above on the basis of the $\Delta^{14} \mathrm{C}$-DOC measured on this day. We have assumed that our random samples represented the actual frequency distribution of discharges. To account for the different size of catchments, the exports were compiled on an area basis (mg C m ${ }^{-2}$ day $^{-1}$; Table S6).

\section{Maps}

The topographical sketch of the historical course of the Elbe river near Magdeburg and the adjacent waters (Figure 2D) was prepared on the basis of two historical maps dating back to the eighteenth century: Charte des Elbstrohms von der Sachsen-Barbyschen Grenze by Schönebeck, 1:10.000, 1739 A.D., obtained from Geheimes Staatsarchiv Preußischer Kulturbesitz Berlin, Rolle 523; Schmettausches Kartenwerk, 1:50.000, 1767-1787 A.D., obtained from Staatsbibliothek zu Berlin Stiftung Preußischer Kulturbesitz, Kart. L 5420 Bl. 87. The present course of the Elbe river (Figure 2E) was derived using data of the German Federal Agency for Cartography and Geodesy $\left({ }^{\odot}\right.$ GeoBasis-DE/BKG 2021, gdz.bkg.bund.de, access June 01, 2021).

\section{Results and Discussion}

\section{Hydrology}

The discharge during the two sampled low flows were exceeded by $98.8 \%$ and $99.3 \%$ of the daily discharge recorded between 1890 and 2018 (Figure 4A). The samples taken during the rising and falling limb of the regular spring peak represented median flow conditions $(48.3 \%, 48.5 \%)$. The four high flows were exceeded by $4.6 \%$ to $0.006 \%$ of daily discharge. The sampled peak flow at June 9, 2013 was the highest discharge event since the start of observation in the year 1727 (Belz and others 2014).

Shifts in the ratio of potassium to calcium in stream water display changes in the generation of the discharge. Calcium is a geogenic tracer of groundwater, while potassium is released by degradation of biomass and a tracer for shallow drainage from soil (Lapp and others 2017). Here, the $\mathrm{K}^{+} / \mathrm{Ca}^{2+}$ ratios were similarly low at both sites of the stream during low flow and median flow and then increased with increasing discharges (Figure 4B). This shows that sources of stream water were similar within the lowest $50 \%$ of streamflows and that surface soils became an increasing source only when discharges exceeded the highest $50 \%$ of streamflows. The higher $\mathrm{K}^{+} / \mathrm{Ca}^{2+}$ ratios at the right side compared to the the left side of the stream during the highest discharges indicate that the $\mathrm{K}^{+} / \mathrm{Ca}^{2+}$ ratios are catchment specific and that lateral mixing of inflowing rivers was not completed at the sampling station.

\section{Sources of Stream Carbon}

We analyzed the sources of TIC and DOC using Keeling plots (Methods). For TIC the regression 
predicts a $\delta^{13} \mathrm{C}$ of $-6 \%$ and a $\Delta^{14} \mathrm{C}$ of $-250 \%$ for the endmember that was significant at low flow (Figure 5A, D). This is typical for groundwater containing a mix of inorganic carbon from the dissolution of carbonate rock $\left(\delta^{13} \mathrm{C} \sim 0 \%\right.$, $\Delta{ }^{14} \mathrm{C}-1000 \%$ ) and inorganic carbon from a modern source $\left(\Delta^{14} \mathrm{C}>0 \%\right)$. The latter is more negative in $\delta^{13} \mathrm{C}$ and can originate from decomposition of topsoil organic carbon (OC), root respiration and silicate weathering (Marx and others 2017; Smits and others 2017). With increasing discharges, groundwater TIC was diluted by inorganic carbon from those modern sources. The $\Delta^{14} \mathrm{C}$-DOC values analyzed for low and median flow (- $212 \%$ to $-137 \%$, Figure 5E) point to aged soil OC as a significant source transported by groundwater (Schiff and others 1997). The corresponding radiocarbon ages ranged from 1850 to 1120 years B.P. The aged DOC was mixed with modern DOC $\left(\Delta^{14} \mathrm{C}\right.$ ca. $\left.200 \%\right)$ fixed during the last years and decades. It most likely originated from organic surface soils.

Based on its age, one may assume that DOC at low flow and median flow was influenced by discharge of $\Delta^{14} \mathrm{C}$-depleted wastewater (Figure 5E). We tested this presumption and calculated a total amount of upstream wastewater inputs of $44 \mathrm{~m}^{3} \mathrm{~s}^{-1}$ for the catchment of the Elbe river at our gauge station. This corresponds to a contribution of $0.9 \%$, $10 \%$ and $30 \%$ of wastewater to the total discharges during peak flow, median flow and low flow, respectively. With respect to carbon flux, the calculated wastewater carbon inputs to the river accounted for only $8 \%$ of stream DOC export on an annual basis. We estimated the $\Delta^{14} \mathrm{C}$ of the nonwastewater stream DOC $\left(\right.$ DOC $\left._{n w}\right)$ by mass balance (Methods). The shaded area in Figure 5E encloses two regression lines predicting the $\Delta^{14} \mathrm{C}-\mathrm{DOC}_{\mathrm{nw}}$ in two scenarios. They show that the $\Delta^{14} \mathrm{C}$ values of the estimated $\mathrm{DOC}_{\mathrm{nw}}$ were similar to the $\Delta^{14} \mathrm{C}$ values of the bulk DOC. Regardless of substantial wastewater discharges, the wastewater did therefore not significantly change the stream $\Delta^{14} \mathrm{C}$-DOC. This result can also be transferred to the $\mathrm{POC}_{n w}$ as in case of the DOC, the published wastewater $\Delta^{14} \mathrm{C}$ POC values (Table S3) were not far from the stream $\Delta^{14} \mathrm{C}$-POC values measured during low flow and median flow. There were only a few radiocarbon data of TIC in WWTP effluent available. Figure 5D shows that if wastewater TIC was present, it was likely not the reason for the radiocarbon-depleted TIC found in the stream.

As an additional source of $\Delta^{14} \mathrm{C}$-negative DOC we need to consider the release of DOC from autochthonous photosynthetic biomass. OC produced by internal photosynthesis carries the ${ }^{14} \mathrm{C}$ signal of the TIC pool as $\Delta^{14} \mathrm{C}$ values are corrected for fractionation, which occurs within the bicarbonate system and during photosynthesis. During low flow and median flow, the TIC was less negative in $\Delta^{14} \mathrm{C}$ than the DOC (Figure 5D, E). At higher flows, the radiocarbon values of the TIC and the DOC were

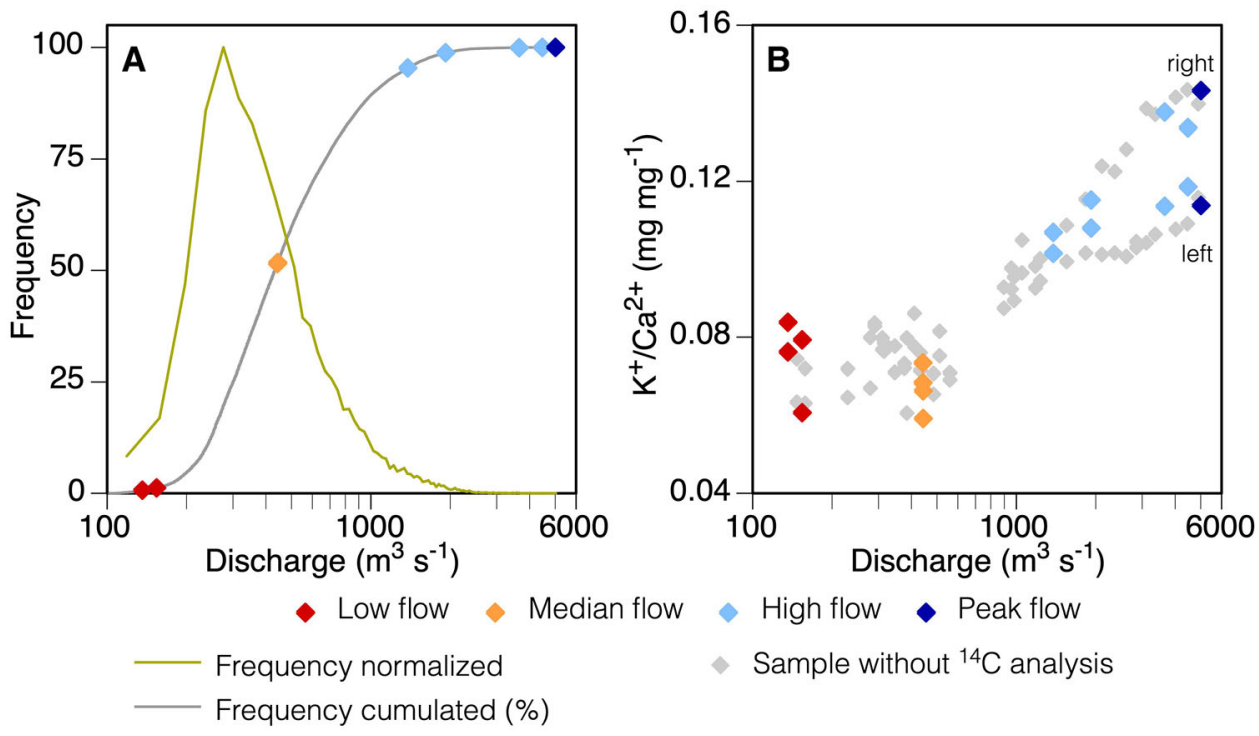

Figure 4. Hydrology. A frequency distribution of discharges recorded between 1890 and 2018 (daily averages), median

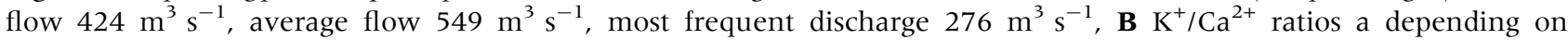
discharge. The ratios base on individual measurements and include samples of the left and right side of the stream. Sampling, in which radiocarbon was also analyzed, is highlighted. 

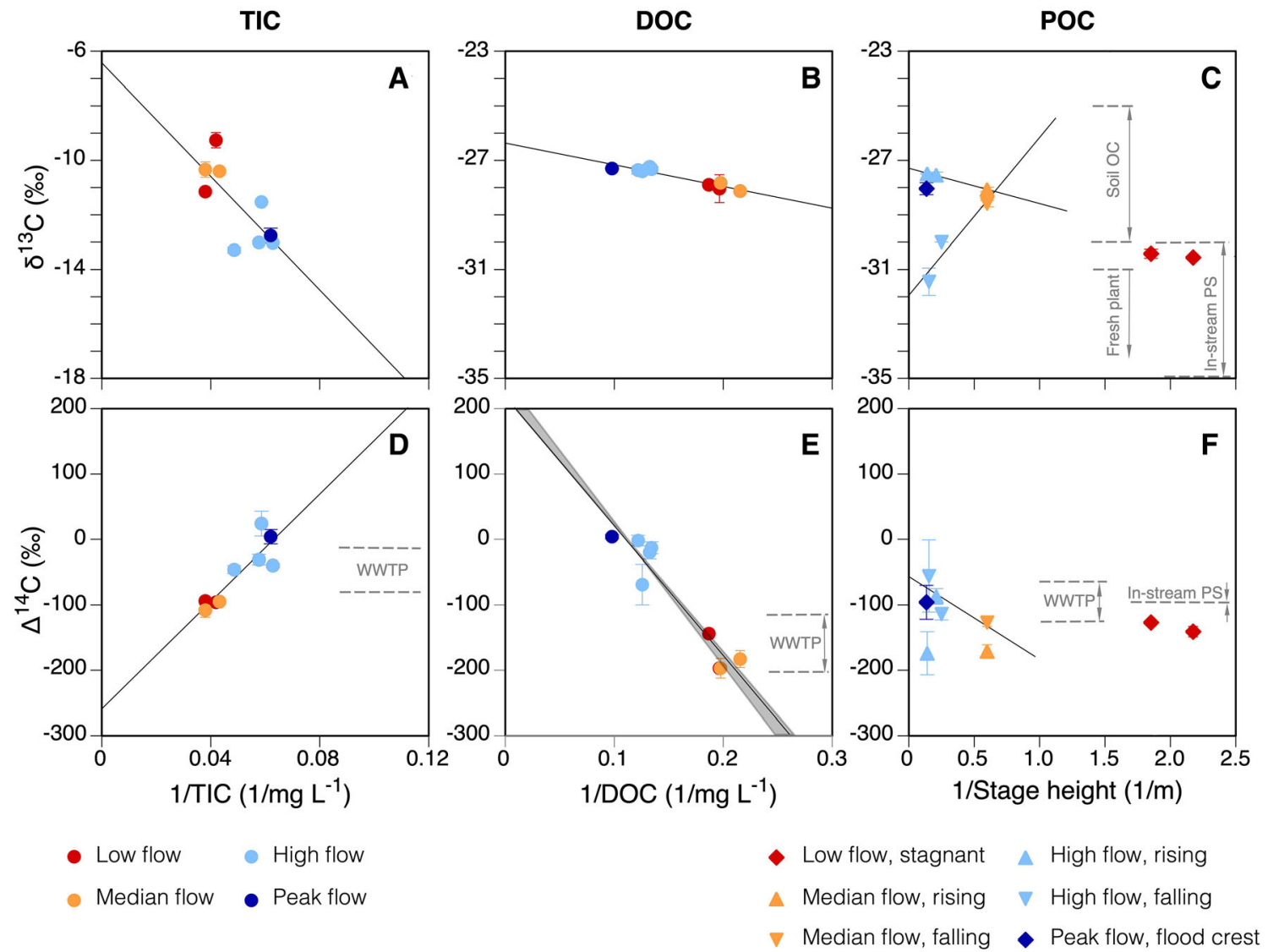

Figure 5. The carbon isotopic composition as function of the reverse of the carbon concentration or stage height. Symbols represent means and ranges of duplicate samples (left and right side of the stream). Dashed lines refer to the ranges of potential carbon sources. For in-stream photosynthesis (PS) that is the isotopic composition of algal OC during low flow. The predicted $\delta^{13} \mathrm{C}$ take into account the isotopic fractionation during photosynthesis (Figure $\mathrm{S} 1$ ), the predicted $\Delta^{14} \mathrm{C}$ was identical to the $\Delta^{14} \mathrm{C}$-TIC in the stream as $\Delta^{14} \mathrm{C}$ values were already corrected for fractionation by convention (Stuiver and Polach 1977). WWTP: effluent of wastewater treatment plants (Methods); fresh plant OC and soil OC data from Clark and others (2013), see text. In panel $\mathbf{E}$ the solid line represents the regression to the measured stream $\Delta^{14} \mathrm{C}$-DOC values (symbols), while the shaded area encloses two regression lines fitted to calculated $\Delta^{14} \mathrm{C}$ values of non-wastewater stream DOC $\left(\right.$ DOC $_{n w}$, close to measured values, symbols not shown). The terms rising, stagnant and falling $(\mathbf{C}, \mathbf{F})$ refer to the change of the stage height. Regressions: $\mathbf{A} \delta^{13} \mathrm{C}$-TIC $=-1041 / \mathrm{TIC}-6.43, R^{2}=0.54, P=0.02427 ; \mathbf{B}, \delta^{13} \mathrm{C}-\mathrm{DOC}=$ $-7.98 \mathrm{l} / \mathrm{DOC}-26.4, R^{2}=0.90, P=0.00009 ; \mathbf{C}$ rising $\delta^{13} \mathrm{C}-\mathrm{POC}=-1.30 \mathrm{l} / \mathrm{Stage}-27.3, R^{2}=1.00, P=0.03925$, falling $\delta^{13} \mathrm{C}$-POC $=5.79 \mathrm{l} / \mathrm{Stage}-31.9, R^{2}=0.90$, n.s.; $\mathbf{D} \Delta^{14} \mathrm{C}$-TIC $=4103 \mathrm{l} / \mathrm{TIC}-259, R^{2}=0.78, P=0.00160 ; \mathbf{E} \Delta^{14} \mathrm{C}-$ $\mathrm{DOC}=-1980 \mathrm{l} / \mathrm{DOC}+219, R^{2}=0.90, P=0.00009 ; \mathbf{F}$, falling $\Delta^{14} \mathrm{C}-\mathrm{POC}=-127 \mathrm{l} / \mathrm{Stage}-56.6, R^{2}=0.62, n . s$. Regressions in $\mathbf{C}$ and $\mathbf{F}$ include only a subset of $N=3$ (2 median flow plus 1 high flow) out of $N=9$ samples, two of these regressions were statistically not significant.

not different. Therefore, DOC released from algal biomass could not have been the source of the old DOC in the river. We also need to discuss the possibility that the selective decomposition of young or of aged DOC by oxidation and microbial respiration affected the $\Delta^{14} \mathrm{C}$ of river DOC. In 2019, during a period with similarly low discharges in the Elbe river as in this study, we incubated DOC from five stations along the German stretch in the laboratory and measured the ${ }^{14} \mathrm{C}$ of the $\mathrm{CO}_{2}$ produced by respiration (Kamjunke and others in prep.). The DOC degradation rates were low $\left(\leq 0.5 \% \mathrm{day}^{-1}\right)$ in upstream parts and increased moderately up to $2.3 \%$ day $^{-1}$ downstream. In parallel, the biomass of the algae had increased and the age of the decomposed DOC closely approached the age of the autochthonous biomass. This indicates that only a small portion of the river DOC and within that portion especially the autochthonously produced DOC was removed. Therefore, we believe that internal decomposition has not significantly changed the $\Delta^{14} \mathrm{C}$ of the river DOC. This interpretation is in line with results from engineered part of the Mississippi river, where the low residence time 
reduces the riverine DOC loss routing more DOC to the downstream deltaic and oceanic environments (Shen and others 2021).

In contrast to DOC and TIC, we obtained POC samples that had similar isotopic compositions but dramatically different POC concentrations. It is conceivable that significant parts of suspended matter can be removed by sedimentation, particularly in lowland rivers, which typically have much lower suspended sediment loads than mountainous rivers (Clark and others 2013). This may weaken or even obscure any relationship between isotopic composition and concentration in these particulate pools, while dissolved compounds (TIC, DOC) still show them. Hence, the mixing model was not applied for POC. We therefore analyzed in which direction the isotopic composition of POC shifted in the succession of hydrological situations. We used the reverse of the river stage as independent variable and distinguished between rising, stagnant (low flow) and falling water levels and the flood crest (Figure 5C, F). At low stages, the $\delta^{13} \mathrm{C}$ and $\Delta{ }^{14} \mathrm{C}$ analyses fell within the range of, or were near to values expected for in-stream photosynthesis (dashed lines). A substantial contribution of algal biomass to POC appears therefore evident at low stage height. This is further supported by high ratios of POC to inorganic suspended solids at low stage heights (POC/ISS $\geq 0.21$, Table S2). At median discharge the $\delta^{13} \mathrm{C}$-POC was less negative and similar during rising and falling water levels (Figure 5 C).

At high river stages, however, the POC isotopic composition diverged. During the rising limb of the hydrograph the $\delta^{13} \mathrm{C}$-POC became less negative, extrapolating to a value of $-27.3 \%$ of the endmember (Figure 5C). Likely, this OC eroded from the river bank and from the stream bed (see below). After the flood crest, the isotopic signatures switched to quite negative values predicting a $\delta^{13} \mathrm{C}$ of $-32 \%$ of the new POC endmember. In general, more negative $\delta^{13} \mathrm{C}$ characterize fresh vegetation $(<-31 \%$ in C3-plant areas), while less negative values $(-25$ to $-30 \%$ ) are typical for soil carbon (Clark and others 2013). An increase in $\delta^{13} \mathrm{C}$ during decomposition of plant biomass is explained by the selective removal of the lighter ${ }^{12} \mathrm{C}$ isotope by microorganisms (Wynn 2007). Here, the switch from a less $\delta^{13} \mathrm{C}$ negative to a more negative POC source indicate that suspended solids from the riverbed were deposited and exchanged with plant debris from the uppermost soil layer of the floodplain areas. This is consistent with a lower POC/ISS ratio at rising stage (0.04) compared to falling stages $(0.22-0.25)$ of the event (Table S2). The
$\Delta^{14} \mathrm{C}$ analyses were generally in agreement with this interpretation, except relatively less negative $\Delta{ }^{14} \mathrm{C}$-POC $\left(-87_{\% o}\right)$ observed in one situation during rising stages (Figure 5F). In contrast to lower stages, a significant contribution of internally produced POC (algae, biofilm) was unlikely due to the small extension of the original stream channel compared to the flooded area and to the lower stream $\Delta^{14} \mathrm{C}$-POC values compared to autochthonous biomass as derived from $\Delta^{14} \mathrm{C}$-TIC measurements (Figure 5D, F).

Overall, aged carbon was found in almost all hydrological situations. Modern organic and modern inorganic carbon was found only during the record peak flow and in the high flow samples taken three days after the peak, that is, during the highest $0.07 \%$ of streamflows. The increase of $\Delta^{14} \mathrm{C}$ values of TIC and DOC started only at water levels above median flow. This supports our conclusion derived from the $\mathrm{K}^{+} / \mathrm{Ca}^{2+}$ ratios that during the lowest $50 \%$ of stream flows surface soils were hydrologically not connected to the stream.

\section{Subcatchments}

Our results agree with the outcome of earlier studies deducing positive relationships between annual precipitation or discharge and $\Delta{ }^{14} \mathrm{C}$-DOC (Butman and others 2012; Butman and others 2014). In their comprehensive data analysis (Butman and others 2014) further observed a decrease in $\Delta^{14} \mathrm{C}$-DOC, that is, an increase in age with the fraction of cultivated and urban area as well as with the population density of the catchment. The authors used the population density as an integrating indicator of human disturbance and related their results to the destabilization of old soil organic matter. Therefore, we addressed the question if anthropogenic destabilization of aged soil OC could be a significant process in the Elbe catchment, explaining the occurrence of ${ }^{14} \mathrm{C}$-depleted DOC $_{n w}$. We compiled radiocarbon measurements from earlier studies in subcatchments of the Elbe river not affected by wastewater (Methods). The $\Delta^{14} \mathrm{C}$ DOC ranged between $-388 \%$ and $101 \%$. We tested if the presence of aged DOC in streams can be related to soil disturbance in their catchments. As independent parameters we used the proportion of (i) arable land, of (ii) pasture, and of (iii) the sum of arable land, pasture plus urban areas of the catchment area. The three linear regressions (i-iii) did not reveal any significant statistical relationships with $\Delta^{14} \mathrm{C}$-DOC $\left(R^{2} \leq 0.01, P \geq 0.33, N=74\right.$ samples). The share of urban areas was too small to test its separate effect. This does not support the 
assumption that soil perturbation was the reason for the old $\mathrm{DOC}_{\mathrm{nw}}$ in the Elbe river.

Next, we selected the streams with entirely forested catchment areas presuming that their DOC isotopic composition was not affected by sewage or soil disturbance. The $\Delta^{14} \mathrm{C}$-DOC of the Elbe river was already shown to be only marginally influenced by sewage (see above), but may still include the effects of soil disturbance in the catchment area. The latter was not supported by land use analyses, but will be further explored here. In the following discussion, we take into account the fact that the amount of stream discharge and the height of the groundwater table are closely coupled (Kendall and others 1999, Bishop and others 2004). Studies in one of our subcatchments confirmed this relationship (Werner and others 2021). At low flows, predominantly groundwater from deeper soil and aquifer layers reaches the stream (Grabs and others 2012) typically containing aged DOC (Schiff and others 1997). With rising discharges, the groundwater increasingly drains shallow soil layers (Seibert and others 2009). Their pore water typically contains modern DOC, that is, carbon that was fixed after 1950 (Ledesma and others 2015; Raeke and others 2017). It can be concluded that the change in DOC isotopic composition along the discharge gradient mirrors the depth of the flow path within the subsurface (Barnes and others 2018). We argue, however, that disturbances from construction or agricultural practices such as tilling mixes the soil and counteracts the formation of vertical gradients (Zummo and Friedland 2011). A relatively low vertical segregation of modern and old carbon will be the consequence. Even old DOC may be released by perturbation of relatively shallow layers: in an undisturbed profile near sampling site 2 (Figure 1), for example, we observed a rapid decrease in the $\Delta^{14} \mathrm{C}$ of soil OC from - $29 \%$ at $8 \mathrm{~cm}$ depth to $-702 \%$ at $81 \mathrm{~cm}$ depth (Tittel and others 2015). Similarly, the release of radiocarbondevoid petrochemical OC from asphalt roads rather diminishes the typically existing vertical ${ }^{14} \mathrm{C}$ gradients in the soil. If soil disturbance or supply of asphalt-derived DOC was the principal cause for the presence of old DOC in the Elbe river, then changes in ${ }^{14} \mathrm{C}$-DOC along the discharge gradient should be hypothesized to remain relatively small, i.e. smaller than at undisturbed sites.

We tested this hypothesis and compared the change in ${ }^{14} \mathrm{C}-\mathrm{DOC}_{\mathrm{nw}}$ in the Elbe river with the change in the $\Delta^{14} \mathrm{C}$-DOC in the streams with entirely forested, that is, undisturbed, subcatchments. The $\Delta^{14} \mathrm{C}$ values increased linearly with the logarithm of the area-specific discharge (Figure 6). At

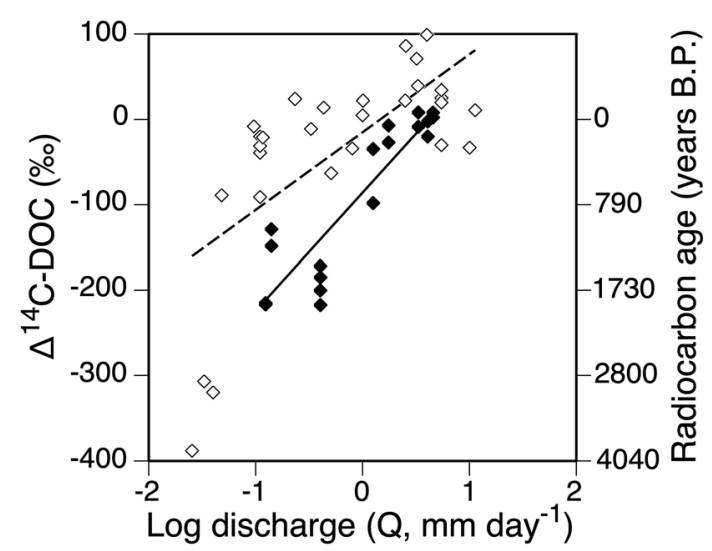

$\diamond$ Subcatchments, forested

- Elbe river

Figure 6. Change of $\Delta^{14} \mathrm{C}$-DOC in the Elbe river and in subcatchment streams with entirely forested catchment areas depending on area-specific discharge at the time of sampling. Regressions: Elbe river, solid line, $\Delta^{14} \mathrm{C}-\mathrm{DOC}_{\mathrm{nw}}$ $($ non-wastewater DOC $)=(139 \pm 17) \cdot \log Q-86, \quad R^{2}=$ 0.81, $F=68, P<0.00001, N=18$; forest streams, broken line, $\Delta^{14} \mathrm{C}-\mathrm{DOC}=(91 \pm 19)^{\circ} \log \mathrm{Q}-15, R^{2}=0.46, F=24$ $P=0.00004, N=30$. Symbols show individual measurements.

the highest discharges, both the Elbe river and forest streams contained modern DOC, but as discharges decreased, $\Delta^{14} \mathrm{C}$ values decreased more rapidly in the Elbe river. The slope for the Elbe river was 1.5 times steeper than the slope for the forest streams. With respect to the hypothesis derived above, a prominent role of soil perturbation for the age of the Elbe river DOC cannot be concluded. Regarding the high population density and arable cultivation in the Elbe catchment this appears surprising. It raises the question to which extent processes in the hinterland, that is, in the upslope area of a catchment can be decisive to the DOC in the river. Indeed, studies showed that hydrologic connectivity of organic, near-stream (riparian) soils constrains DOC export (Inamdar and Mitchell 2006; Sanderman and others 2009). From carbon pools and lateral exports of 13 boreal soil profiles Ledesma and others (2015) concluded that $90 \%$ of the potential DOC flux originated just from an approximately $36 \mathrm{~cm}$ thick layer in the riparian zone. We, therefore, focus in the following on the stream network and the riparian zones.

\section{Stream Geomorphology}

Like many other rivers in Europe, the Americas and Australia (Brown and others 2018, Shen and others 2021), the catchment area and the network 
of the Elbe river has been strongly anthropogenically transformed (Figure 2). In general, increasing overbank accumulation is combined with decreasing groundwater levels (see Introduction, site description above). In the middle reaches of the Elbe river, in a stretch between Mühlberg and Magdeburg, the river bed has deepened 0.5-2.0 m (Koenig and others 2012), which inevitably lowered the groundwater tables in near-stream areas. From the border of the Czech Republic to the mouth of the Saale river, only about $2-7 \%$ or less of floodplain areas are inundated up to discharges twice as high as the mean flow $\left(1100 \mathrm{~m}^{3} \mathrm{~s}^{-1}\right.$ at our gauge station), that is, during $91 \%$ of all streamflow situations (Krüger and others 2015). Consistent with these observations our POC isotope data had shown that deposition on and erosion from floodplain soils only started at stages higher than median flow (Figure 5C, F). Similarly, the sources of stream water and the sources of TIC and DOC remained the same during the lowest $50 \%$ of stream flows; there was no increase in ${ }^{14} \mathrm{C}$ when the river stage and presumably the groundwater table height (Figure 5D, E) increased from low flow to median flow. This indicated that the stores of recently fixed carbon, that is, the floodplain surface soils were largely disconnected from the stream in half of all hydrological situations. Here, we propose that anthropogenic activities have transformed the geomorphology of many rivers, which has lowered the groundwater tables in near-stream areas relative to overbank sediments and shifted the sources of fluvial carbon in favor of aged stores.

Wetlands flanking the river, floodplain waterways and oxbow lakes are integral parts of lowland river networks and represent vast stores of plant biomass. In a study of a North American catchment and estuary, Raymond and Hopkinson (2003) estimated that wetlands could be responsible for $75 \%$ of the DOC export. The DOC added from wetlands was ${ }^{14} \mathrm{C}$-enriched and is therefore referred to as modern. We calculated the share of modern carbon in the DOC export in our forest streams and in the Elbe river main channel (Methods). In the forest streams $72 \%$ of the exported DOC was modern (Figure 7). In contrast modern DOC only accounted for a marginal fraction $(0.04 \%)$ of the time-integrated DOC export of the enclosing Elbe catchment, whereas $72 \%$ of the DOC was older than 400 years and $40 \%$ was older than 800 years. We interpret this result with the disconnection of recently fixed OC of floodplain surface soils, in particular of organic near-stream

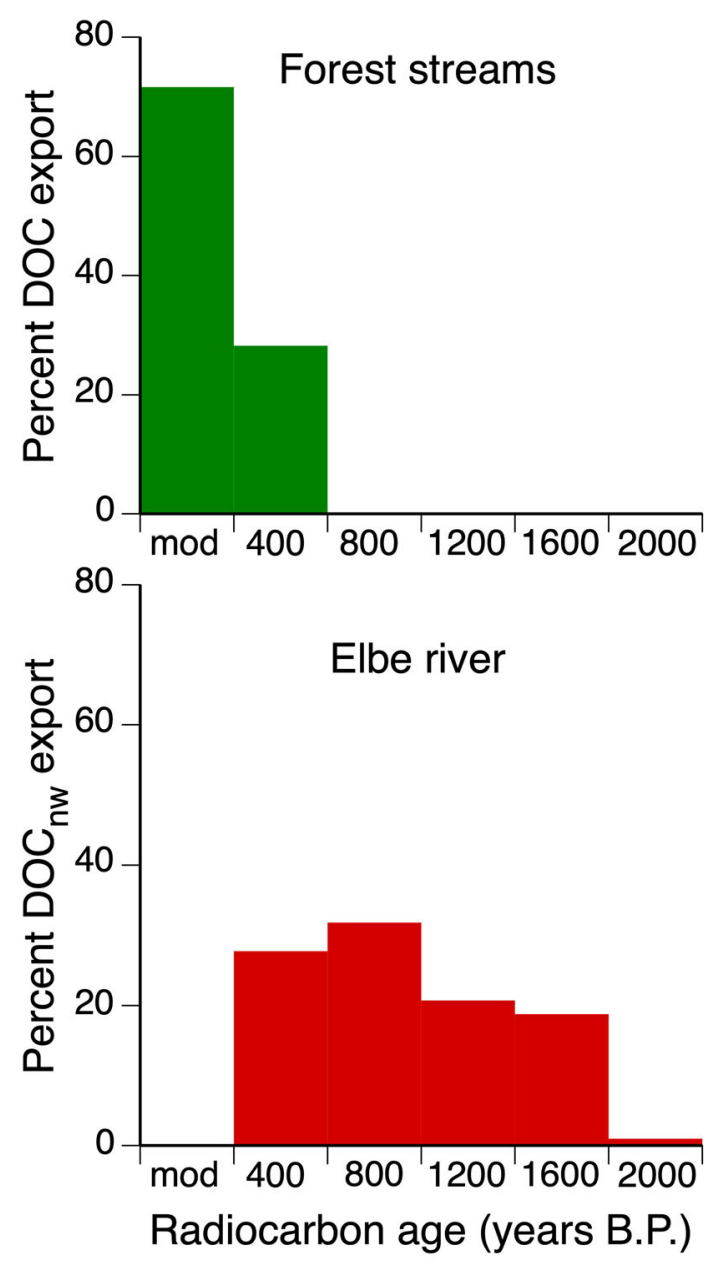

Figure 7. The age distribution of the exported DOC in the Elbe river and in forested subcatchments. An insignificant portion of the DOC export of forest streams was older than 2000 years $(0.02 \%$, not shown).

areas typically having a high groundwater table, i.e. the floodplain wetlands. The latter are almost infinite sources of OC (Raymond and Hopkinson 2003; Inamdar and Mitchell 2006). However, wetlands can lose their connection to the stream if the channel incises and eventually dries up. The section of the Elbe river at our sample site exemplifies this development (Figure 2D, E). For a stretch of the middle Elbe upstream the Mulde tributary that was particularly affected by bed erosion, Knösche and others (2001) estimated that between the 1950s and the 1990s $40 \%$ of the floodplain area was lost. Our data suggest that those structural changes of the network decoupled wetlands and other sources of contemporary carbon from the river and ultimately have led to the dominance of carbon exports from old stores. 


\section{Implications}

The Elbe is primarily a lowland river draining a glacially conditioned landscape. Its OC sources are younger and less different in age compared to mountainous rivers incising old sedimentary bedrock typically containing ${ }^{14} \mathrm{C}$-dead petrogenic OC (Rosenheim and Galy 2012; Clark and others 2013). Hence, the results of our study cannot be transferred to these erosive rivers. Furthermore, our results do not exclude that high wastewater discharges may increase the carbon age in rivers. We suggest that human settlement along the rivers, conversion of floodplains to agricultural land and channelization has dramatically changed the geomorphology of many streams and modified the amount and composition of the fluvial carbon. If recently fixed carbon stores are hydrologically less well connected, this means that a lower proportion of carbon can be channeled out of the rapidly cycling pools of the biosphere and eventually buried in ocean basins. Also, higher amounts of base cations $\left(\mathrm{Ca}^{2+}\right.$, Figure 4$)$ will be exported by rivers.

Terrestrial and aquatic systems quickly recycle a large portion of the recently fixed carbon, while only a small fraction remains in the system longer. Therefore, the $\mathrm{CO}_{2}$ evading from soils either directly or via fluvial pathways is typically modern and tracks the ${ }^{14} \mathrm{C}$ signal of the atmospheric $\mathrm{CO}_{2}$ (Trumbore 2000; Campeau and others 2019), whereas the soil $\mathrm{OC}$ is on average $3100 \pm 1800$ years old (He and others 2016). Undisturbed peatland releases predominantly modern DOC and $\mathrm{CO}_{2}$ from peat profiles whose OC is centuries old (Evans and others 2014; Leith and others 2014). In addition, large lake ecosystems bury only about $3 \%$ of their autochthonous production in sediments, the rest being subsequently oxidized (Alin and Johnson 2007). Our results from forest streams exporting predominantly modern DOC was in line with these observations. However, the DOC export from the enclosing Elbe catchment was not. Its age distribution emphasizes the profound changes in solute transport of lowland drainage systems when their network is anthropogenically modified and engineered.

Our findings have implications for the management of river networks and point to the requirement to keep the river channel well connected to its floodplains. The avoidance of progressive channel incising and dropping groundwater tables is a key issue here. This alone is certainly not a new statement among river researchers. But our study adds an important new aspect to this debate as we documented that the conversion of stream net- works to engineered waterways is going to change carbon cycling along catchments and the carbon exports from land ecosystems to coastal oceans.

\section{ACKNOWLEDGEMENTS}

We would like to thank the staff at the Leibniz Laboratory Kiel for processing and measuring the radiocarbon samples. We also thank the staff at the Stable Isotope Facility Davis and the staff at the Stable Isotope Laboratory Flagstaff for analyzing the ${ }^{13} \mathrm{C}$ isotopes. Yvonne Rosenlöcher, Ute Link and Erika Ruschak supported the field sampling. Ina Siebert, Brunhilde Keller and Heike Goreczka performed chemical analyses. Claudia Neitzel supported the preparation of the maps. Comments by Norbert Kamjunke and by two reviewers greatly improved the manuscript. We thank the Staatsbibliothek zu Berlin Preußischer Kulturbesitz and the Geheimes Staatsarchiv Preußischer Kulturbesitz Berlin for providing historical maps.

\section{FUNDING}

Open Access funding enabled and organized by Projekt DEAL.

\section{OPEN ACCESS}

This article is licensed under a Creative Commons Attribution 4.0 International License, which permits use, sharing, adaptation, distribution and reproduction in any medium or format, as long as you give appropriate credit to the original author(s) and the source, provide a link to the Creative Commons licence, and indicate if changes were made. The images or other third party material in this article are included in the article's Creative Commons licence, unless indicated otherwise in a credit line to the material. If material is not included in the article's Creative Commons licence and your intended use is not permitted by statutory regulation or exceeds the permitted use, you will need to obtain permission directly from the copyright holder. To view a copy of this licence, visit $h$ ttp://creativecommons.org/licenses/by/4.0/.

\section{REFERENCES}

Alin SR, Johnson TC. 2007. Carbon cycling in large lakes of the world: a synthesis of production, burial, and lake-atmosphere exchange estimates. Glob Biogeochem Cycles 21:GB3002

Barnes RT, Butman DE, Wilson HF, Raymond PA (2018) Riverine export of aged carbon driven by flow path depth and residence time. Environ Sci Technol 52:1028-1035. 
Belz JU, Adler M, Baschek B, Belz JU, Bergfeld-Wiedemann T, Brockmann H, Busch N, Claes J, Daedlow K, Hammer M, Hatz M, Hillebrand G, Hübner G, Klein B, Kleisinger C, Krahe P, Larina-Pooth M, Meißner D, Mothes D, Mürlebach M, Nilson E, Otto W, Promny M, Rademacher S, Schöl A, Schriever S, Schubert B, Schwandt D, Viergutz C (2014) Das Hochwasserextrem des Jahres 2013 in Deutschland: Dokumentation und Analyse. Page 232 Mitteilungen. Bundesanstalt für Gewässerkunde, Koblenz

Berner RA (2003) The long-term carbon cycle, fossil fuels and atmospheric composition. Nature 426:323-326.

Bishop K, Seibert J, Köhler S, Laudon H. 2004. Resolving the Double Paradox of rapidly mobilized old water with highly variable responses in runoff chemistry. Hydrol Process 18:185-189.

Brázdil R, Máčka Z, Řezníčková L, Soukalová E, Dobrovolný P, Grygar TM. 2011. Floods and floodplain changes of the River Morava, the Strážnické Pomoraví region (Czech Republic) over the past 130 years. Hydrol Sci J 56:1166-1185.

Brown AG, Lespez L, Sear DA, Macaire J-J, Houben P, Klimek K, Brazier RE, Van Oost K, Pears B. 2018. Natural vs anthropogenic streams in Europe: History, ecology and implications for restoration, river-rewilding and riverine ecosystem services. Earth-Sci Rev 180:185-205.

Butman D, Raymond PA, Butler K, Aiken G (2012) Relationships between $\triangle 14 \mathrm{C}$ and the molecular quality of dissolved organic carbon in rivers draining to the coast from the conterminous United States. Glob Biogeochem Cycles 26

Butman DE, Wilson HF, Barnes RT, Xenopoulos MA, Raymond PA. 2014. Increased mobilization of aged carbon to rivers by human disturbance. Nat Geosci 8:112-116.

Campeau A, Bishop K, Amvrosiadi N, Billett MF, Garnett MH, Laudon H, Öquist MG, Wallin MB. 2019. Current forest carbon fixation fuels stream $\mathrm{CO} 2$ emissions. Nat Commun 10:1876.

Clark KE, Hilton RG, West AJ, Malhi Y, Gröcke DR, Bryant CL, Ascough PL, Robles Caceres A, New M. 2013. New views on "old" carbon in the Amazon River: Insight from the source of organic carbon eroded from the Peruvian Andes. Geochem Geophys Geosyst 14:1644-1659.

Drake TW, Raymond PA, Spencer RGM. 2018. Terrestrial carbon inputs to inland waters: a current synthesis of estimates and uncertainty. Limnol Oceanogr Lett 3:132-142.

EEA (2018) Corine Land Cover (CLC) 2012, Version 18.5.1 Release date: 19-09-2016

Eurostat (2015) GEOSTAT $1 \mathrm{~km} 2$ population grid 2011, version V2.0.1. European Commission

Evans CD, Page SE, Jones T, Moore S, Gauci V, Laiho R, Hruška J, Allott TEH, Billett MF, Tipping E, Freeman C, Garnett MH. 2014. Contrasting vulnerability of drained tropical and highlatitude peatlands to fluvial loss of stored carbon. Glob Biogeochem Cycles 28:1215-1234.

Friese K, Witter B, Brack W, Buettner O, Krueger F, Kunert M, Rupp H, Miehlich G, Groengroeft A, Schwartz R, van der Veen A, Zachmann W. 2000. Distribution and fate of organic and inorganic contaminants in a river floodplain-results of a case study on the River Elbe, Germany. In: Wise DL, Trantole DJ, Cichon EJ, Inyang HI, Stottmeister U, Eds. Remediation engineering of contaminated sites, . New York, Basel: Marcel Dekker. pp 375-428.

Galy V, France-Lanord C, Beyssac O, Faure P, Kudrass H, Palhol F. 2007. Efficient organic carbon burial in the Bengal fan sustained by the Himalayan erosional system. Nature 450:407-410.

Grabs T, Bishop K, Laudon H, Lyon SW, Seibert J. 2012. Riparian zone hydrology and soil water total organic carbon (TOC): implications for spatial variability and upscaling of lateral riparian TOC exports. Biogeosciences 9:3901-3916.

Griffith DR, Barnes RT, Raymond PA. 2009. Inputs of fossil carbon from wastewater treatment plants to U.S. rivers and oceans. Environ Sci Technol 43:5647-5651.

He Y, Trumbore SE, Torn MS, Harden JW, Vaughn LJS, Allison SD, Randerson JT. 2016. Radiocarbon constraints imply reduced carbon uptake by soils during the 21 st century. Science 353:1419-1424.

Hossler K, Bauer JE. 2013. Amounts, isotopic character, and ages of organic and inorganic carbon exported from rivers to ocean margins: 1. estimates of terrestrial losses and inputs to the Middle Atlantic Bight. Glob Biogeochem Cycles 27:331-346.

Inamdar SP, Mitchell MJ. 2006. Hydrologic and topographic controls on storm-event exports of dissolved organic carbon (DOC) and nitrate across catchment scales. Water Resour Res 42:W03421.

Jawitz JW, Mitchell J (2011) Temporal inequality in catchment discharge and solute export. Water Resour Res 47

Kendall KA, Shanley JB, McDonnell JJ. 1999. A hydrometric and geochemical approach to test the transmissivity feedback hypothesis during snowmelt. J Hydrol 219:188-205.

Knösche R, Zahn S, Schoppe P, Ebel H (2001) Fische und Fischerei in der Mittelelbe. Pages 1-99. Institut für Binnenfischerei e.V. Potsdam-Sacrow, Groß-Glienicke, Germany

Koenig F, Quick I, Vollmer S (2012) Defining quantitative morphological changes in large rivers for a sustainable and effective sediment management applied to the River Elbe, Germany.in Proceedings of the Tenth International Conference on Hydroscience \& Engineering, Rosen Plaza Hotel Orlando, Florida

Krüger F, Schwartz R, Kunert M, Friese K. 2006. Methods to calculate sedimentation rates of floodplain soils in the middle region of the Elbe River. Acta Hydrochimica Et Hydrobiologica 34:175-187.

Krüger F, Scholz M, Kreibich M, Baborowski M. 2015. Sediment retention in the floodplains of the river Elbe (in German). Hydrologie Und Wasserbewirtschaftung 59:380-395.

Lapp A, Clark I, Macumber A, Patterson T. 2017. Hydrology of the North Klondike River: carbon export, water balance and inter-annual climate influences within a sub-alpine permafrost catchment. Isotopes Environ Health Stud 53:500-517.

Ledesma JLJ, Grabs T, Bishop KH, Schiff SL, Kohler SJ. 2015. Potential for long-term transfer of dissolved organic carbon from riparian zones to streams in boreal catchments. Glob Change Biol 21:2963-2979.

Leith FI, Garnett MH, Dinsmore KJ, Billett MF, Heal KV. 2014 Source and age of dissolved and gaseous carbon in a peatlandriparian-stream continuum: a dual isotope (14C and $\delta 13 \mathrm{C})$ analysis. Biogeochemistry 119:415-433.

Lorrain A, Savoye N, Chauvaud L, Paulet Y-M, Naulet N. 2003. Decarbonation and preservation method for the analysis of organic $\mathrm{C}$ and $\mathrm{N}$ contents and stable isotope ratios of lowcarbonated suspended particulate material. Anal Chim Acta 491:125-133.

Marx A, Dusek J, Jankovec J, Sanda M, Vogel T, van Geldern R, Hartmann J, Barth JAC. 2017. A review of CO2and associated 
carbon dynamics in headwater streams: a global perspective. Rev Geophys 55:560-585.

Pataki DE, Ehleringer JR, Flanagan LB, Yakir D, Bowling DR, Still CJ, Buchmann N, Kaplan JO, Berry JA .2003. The application and interpretation of Keeling plots in terrestrial carbon cycle research. Global Biogeochem Cycles 17:1022.

Raeke J, Lechtenfeld OJ, Tittel J, Oosterwoud MR, Bornmann K, Reemtsma T. 2017. Linking the mobilization of dissolved organic matter in catchments and its removal in drinking water treatment to its molecular characteristics. Water Res 113:149159.

Raška P, Dolejš M, Hofmanová M. 2017. Effects of damming on long-term development of Fluvial Islands, Elbe River (N Czechia). River Res Appl 33:471-482.

Raymond PA, Bauer E. 2001. Riverine export of aged terrestrial organic matter to the North Atlantic Ocean. Nature 409:497500 .

Raymond PA, Hopkinson CS. 2003. Ecosystem modulation of dissolved carbon age in a temperate marsh-dominated estuary. Ecosystems 6:694-705.

Rommel J (2001) Studie zur Laufentwicklung der deutschen Elbe bis Geesthacht seit ca. 1600. Bundesanstalt füer Gewässerkunde, Koblenz, Germany

Rosenheim BE, Galy V (2012) Direct measurement of riverine particulate organic carbon age structure. Geophys Res Lett 39:L19703.

Sanderman, J., K. A. Lohse, J. A. Baldock, and R. Amundson. 2009. Linking soils and streams: Sources and chemistry of dissolved organic matter in a small coastal watershed. Water Resources Research 45.

Schiff SL, Aravena R, Trumbore SE, Hinton MJ, Elgood R, Dillon PJ. 1997. Export of DOC from forested catchments on the Precambrian Shield of Central Ontario: Clues from 13C and 14C. Biogeochemistry 36:43-65.

Schneeweiss J, Schatz T. 2014. The impact of landscape change on the significance of political centres along the lower Elbe River in the 10th century A.D. Quat Int 324:20-33.

Seibert J, Grabs T, Köhler S, Laudon H, Winterdahl M, Bishop K. 2009. Linking soil- and stream-water chemistry based on a Riparian Flow-Concentration Integration Model. Hydrol Earth Syst Sci 13:2287-2297.
Shen Z, Rosenheim BE, Törnqvist TE, Lang A. 2021. Engineered continental-scale rivers can drive changes in the carbon cycle. AGU Advances 2:e2020AV000273.

Sickman JO, Zanoli MJ, Mann HL (2007) Effects of urbanization on organic carbon loads in the Sacramento River, California. Water Resour Res 43:W11422.

Smits AP, Schindler DE, Holtgrieve GW, Jankowski KJ, French DW. 2017. Watershed geomorphology interacts with precipitation to influence the magnitude and source of $\mathrm{CO}_{2}$ emissions from Alaskan streams. J Geophys Res Biogeosci 122:19031921.

Stuiver M, Polach HA. 1977. Reporting of C-14 Data - Discussion. Radiocarbon 19:355-363.

Tena A, Piégay H, Seignemartin G, Barra A, Berger JF, Mourier B, Winiarski T. 2020. Cumulative effects of channel correction and regulation on floodplain terrestrialisation patterns and connectivity. Geomorphology 354:107034.

Tittel J, Büttner O, Freier K, Heiser A, Sudbrack R, Ollesch G. 2013. The age of terrestrial carbon export and rainfall intensity in a temperate river headwater system. Biogeochemistry 115:53-63.

Tittel J, Müller C, Schultze M, Musolff A, Knöller K. 2015. Fluvial radiocarbon and its temporal variability during contrasting hydrological conditions. Biogeochemistry 126:57-69.

Trumbore S. 2000. Age of soil organic matter and soil respiration: radiocarbon constraints on belowground $\mathrm{C}$ dynamics. Ecol Appl 10:399-411.

Werner BJ, Lechtenfeld OJ, Musolff A, de Rooij GH, Yang J, Gründling R, Werban U, Fleckenstein JH. 2021. Patterns and dynamics of dissolved organic carbon exports from a riparian zone of a temperate, forested catchment. Hydrol Earth Syst Sci Discuss 2021:1-27.

Wynn JG. 2007. Carbon isotope fractionation during decomposition of organic matter in soils and paleosols: Implications for paleoecological interpretations of paleosols. Palaeogeogr Palaeoclimatol Palaeoecol 251:437-448.

Zummo LM, Friedland AJ. 2011. Soil carbon release along a gradient of physical disturbance in a harvested northern hardwood forest. For Ecol Manag 261:1016-1026. 